\title{
異方性Ba- $\mathrm{Zn}-\mathrm{Cu}$ 系W型フェライト磁石の諸特性
}

\author{
正員 山元 洋 \\ (明治大学理工学部) \\ 非会員 鈴木 宏一 \\ (明治大学理工学部)

\section{Properties of Anisotropic $\mathrm{Ba}-\mathrm{Zn}-\mathrm{Cu}$ System W-Type Hexagonal Ferrite Magnets.}

\author{
Hiroshi Yamamoto, Member and Koichi Suzuki, Non-Member \\ (School of Science and Technology, Meiji University)
}

\begin{abstract}
Experiments were carried out to investigate on the magnetic and physical properties of $\mathrm{Ba}-\mathrm{Zn}-\mathrm{Cu}$ W-type hexagonal ferrites sintered without atmosphere control. Composition were chosen according to the formula $\mathrm{BaZn}_{2-\mathrm{X}} \mathrm{Cu}_{\mathrm{X}} \mathrm{Fe}_{16} \mathrm{O}_{27}$, where $\mathrm{X}$ was varied $0 \sim 0.5$ and 1.0. The effect of $\mathrm{BaO}$ addition after semisintering treatment on magnetic properties of $\mathrm{Ba}-\mathrm{Zn}-\mathrm{Cu}$ compounds was examinend. It was found that $\mathrm{BaO}$ addition for $\mathrm{Ba}-\mathrm{Zn}-\mathrm{Cu}$ compounds was very useful in stabilizing the $\mathrm{W}$-type hexagonal. The optimum condition of making magnets and some properties of a typical specimens are as follows : composition; $\mathrm{BaZn}_{1.7} \mathrm{Cu}_{03} \mathrm{Fe}_{16} \mathrm{O}_{27}$ in addition with $4 \mathrm{wt} \% \mathrm{BaO}$, semisintering condition 1275 ${ }^{\circ} \mathrm{C}$ for $1.0 \mathrm{~h}$ in air, sintering condition $1175{ }^{\circ} \mathrm{C}$ for $0.5 \mathrm{~h}$ in air , magnetic properties and lattice constant are $\mathrm{J}_{\mathrm{rm}}=0.405 \mathrm{~T}, \mathrm{~J}_{\mathrm{r}}=0.370 \mathrm{~T}, \mathrm{H}_{\mathrm{dj}}=88.15 \mathrm{kA} / \mathrm{m}, \mathrm{H}_{\mathrm{cB}}=81.96 \mathrm{kA} / \mathrm{m},(B H)_{\max }=19.12 \mathrm{~kJ} / \mathrm{m}^{3}, \mathrm{~T}_{\mathrm{c}}=356^{\circ} \mathrm{C}$, $\mathrm{H}_{\mathrm{A}}=994.7 \mathrm{kA} / \mathrm{m}, \mathrm{K}_{\mathrm{A}}=2.01 \times 10^{5} \mathrm{~J} / \mathrm{m}^{3}, \quad c=32.928 \times 10^{-10} \mathrm{~m}, \quad \mathrm{a}=5.927 \times 10^{-10} \mathrm{~m}, \mathrm{c} / \mathrm{a}=5.556$
\end{abstract}

キーワード：Ba-Zn-Wフェライト，磁気特性， $\mathrm{H}_{\mathrm{c}}$ 及び $\sigma_{\mathrm{s}}$ の温度依存性，異方性定数及び異方性磁界

\section{1 緒言}

W型六方晶フェライトの研究は，これまでに数多く報告

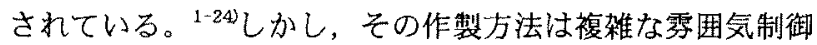
が必要であり，現在のところ工業化は難しいとされている。 先に著者らの一人は, $\mathrm{BaO} \cdot 2 \mathrm{ZnO} \cdot 8 \mathrm{Fe}_{2} \mathrm{O}_{3}$ 化合物は $\mathrm{BaO}$ を仮焼成後に添加することにより霛囲気制御を行わずに，

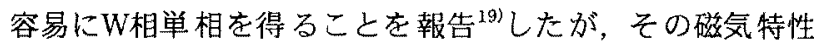
は十分なものが得られなかった。また，豊田ら 田ら ${ }^{221}$ 怯窑素中で焼成することにより良好な磁気特性が得 られたと報告したが，作製は難しいようである。そこで本 研究は大気中焼成という条件のもと，F.Licci,L.paretiら ${ }^{9110)}$ 及び小島ら ${ }^{11 /}$ の報告を参考に2酶の金属イオンをZnとし たW型六方晶フェライトにおいて $\mathrm{Zn}^{2+}$ の一部を $\mathrm{Cu}^{2+}$ に置換 し，更にこの置換後，BaOを途中添加することにより，組 成及び焼成条件などが磁気的，物理的特性に及ぼす影響に ついて詳細に実験，検討を行った。

\section{2 実験方法}

実娩に用いた原材料は $\mathrm{BaCO}_{3}, \mathrm{ZnO}, \mathrm{CuO}, \alpha-\mathrm{Fe}_{2} \mathrm{O}_{3}$ 粉末 である。組成はBaZn $\mathrm{Bu}_{2-\mathrm{x}} \mathrm{Cu}_{\mathrm{x}} \mathrm{Fe}_{16} \mathrm{O}_{27}$ において置換量を0〜 $0.5,1.0$ と変化させた。秤量は原材料索用いて各組成が $0.3 \mathrm{~kg}$ になるように行い, 混合はボールミル（湿式法で 3h行った。これら混合された試料を乾燥後, 仮焼成試料と してプレス圧 $49 \mathrm{MPa}$ でゅ $36 \mathrm{~mm} \times 7 \mathrm{~mm}$ の円柱状に成形した。 成形した試料は管状電気柜を用いて大気中で $1225 \sim 1300^{\circ} \mathrm{C}$ で1h仮焼成を行った。この仮焼成した試料を $150 \mu \mathrm{m}$ 以下 に粉砕した後ステンレス製振動ボールミル（湿式法）を用 いて8h粉砕した。粉砕された泥状仮焼成粉末を $800 \mathrm{kA} / \mathrm{m}$ の磁界中（縦磁場）においてプレス圧 $294 \mathrm{MPa}$ で $\phi 13 \mathrm{~mm}$ ×11 13mmの円柱状に成形した。本焼成は, 大気中で $1150 \sim 1275^{\circ} \mathrm{C}$ 温度範围で 0.5 h焼成した。試料の諸特性 は, 磁気特性については高感度磁気磁束計及び振動試料型 磁力計(VSM)で测定した。また密度は水中法で, 組織は走 查型電子顕微鏡(SEM)で, 磁区模様はビッター法を用い, 結晶構造忹線粉末法を用いて検討した。また，Cu置換し たことにより磁気特性の向上がタられたものについては， 仮焼成後の粉砕時にBaOt添加し、上記と同様に諸特性の 測定を行った。

\section{3 実験結果並びに考察}

まず始めに, $\mathrm{BaZn} \mathrm{n}_{2 \mathrm{x}} \mathrm{Cu}_{\mathrm{x}} \mathrm{Fe}_{16} \mathrm{O}_{27}$ 組成において $\mathrm{Cu}$ 置換量 $\mathrm{X}=0 \sim 0.5,1.0$ まで变化させ，仮焼成後 $\left(1275^{\circ} \mathrm{C} \times 1 \mathrm{~h}\right)$ の粉末 のX線回折を行った結果, 全ての置換量においてW相単相 が得られた。そこで以降これらの化合物において異方性焼 結磁石を作製し，磁気特性についての評価を行った。 
Fig.1は組成式 $\mathrm{BaZn}_{2-x} \mathrm{Cu}_{\mathrm{x}} \mathrm{Fe}_{16} \mathrm{O}_{27}$ において $\mathrm{Cu}$ 置換量 $\mathrm{X}=0 \sim 0.5,1.0$ としたときの磁気特性を示している。な お，仮焼成は今までの著者ら ${ }^{12), 19-20)}$ の実煥で最 も良かった $1275^{\circ} \mathrm{C} \times 1.0 \mathrm{~h}$ ，本焼成条件は $1250^{\circ} \mathrm{C} \times 0.5 \mathrm{~h}$ と し，大気中で行った。図から知られるように， $\mathrm{J}_{\mathrm{m}}, \mathrm{J}_{\mathrm{r}}$ はCu 置換量X $=0.3$ で最大値を示し, 以降置換量の增加に伴いほ ぼ一定値となった。 $\mathrm{H}_{\mathrm{d}}, \mathrm{H}_{\mathrm{B}}$ は置換量の変化に対しそれほ ぞ大きな変化は見られなかった。 $(\mathrm{BH})_{\max }$ は， $\mathrm{Cu}$ 置換量 $\mathrm{X}=0.3$ とき最大值を示した。

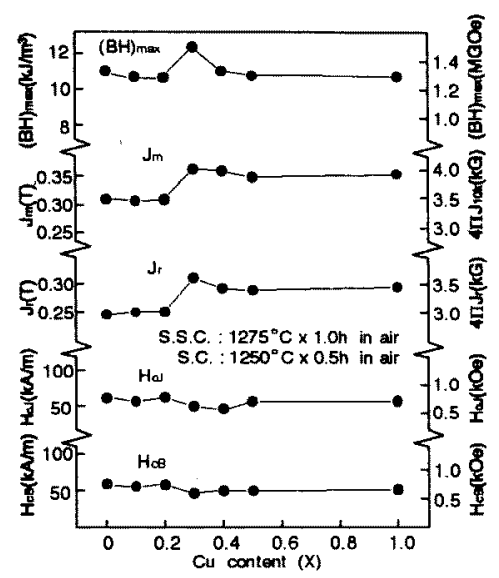

园1 $\mathrm{BaZn}_{2-\mathrm{x}} \mathrm{Cu}_{\mathrm{x}} \mathrm{Fe}_{16} \mathrm{O}_{27}$ 化合物の磁気特性 に及ぼすCu置換の影響

Fig.1 Effect of $\mathrm{Cu}$ content on magnetic properties of $\mathrm{BaZn}_{2-\mathrm{X}} \mathrm{Cu}_{\mathrm{X}} \mathrm{Fe}_{16} \mathrm{O}_{27}$ compounds.

Fig.2は組成式 $\mathrm{BaZn}_{2-\mathrm{x}} \mathrm{Cu}_{\mathrm{x}} \mathrm{Fe}_{16} \mathrm{O}_{27}$ に扔いて, 置換量を 0,0.2 0.4まで変化させ, 本焼成条件 $\left(1175 \sim 1275^{\circ} \mathrm{C} \times\right.$ 0.5h）と磁気特性の関倸を表わしたものである。な挔，仮 锛成条件は $1275^{\circ} \mathrm{C} \times 1.0 \mathrm{~h}$ 一定としている。図加ら知ら

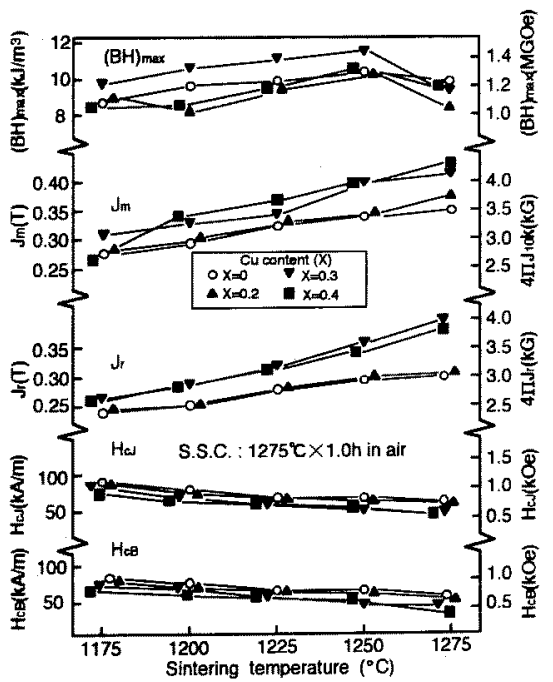

図2 $\quad \mathrm{BaZn}_{2-\mathrm{x}} \mathrm{Cu}_{\mathrm{x}} \mathrm{Fe}_{16} \mathrm{O}_{27}$ 化合物の磁気特性に 及ぼす本焼成温度の影響

Fig.2 Effect of sintering temperature on magnetic properties of $\mathrm{BaZn}_{2-\mathrm{x}} \mathrm{Cu}_{\mathrm{X}} \mathrm{Fe}_{16} \mathrm{O}_{27} \mathrm{com}^{-}$ pounds.

れるように $\mathrm{J}_{\mathrm{m}} \mathrm{J}_{\mathrm{r}}$ はCu置換全ての組成で本焼成温度の上昇と 共に增加し， $\mathrm{H}_{\mathrm{o}}, \mathrm{H}_{\mathrm{cB}}$ 性本焼成温度の上昇に伴い減少するこ とが知られた。これは一般の焼結磁石と同様の傾向を示し た。また $(\mathrm{BH})_{\max }$ は $\mathrm{Cu}$ 置掺量 $\mathrm{X}=0.3$, 本狫成温度 $1250^{\circ} \mathrm{C}$ の 時最大值を示した。そこで以後の実験は, $\mathrm{Cu}$ 置換量 $\mathrm{X}=0.3$ を最適置換量とした。

次にこれらの相の解析を行った。Table1は組成式 $\mathrm{BaZn}_{2-\mathrm{x}} \mathrm{Cu}_{\mathrm{x}} \mathrm{Fe}_{16} \mathrm{O}_{27}$ におけるCu置換量をX=0〜0.5,1.0, 本 焼成温度を $1150 \sim 1275^{\circ} \mathrm{C} \times 0.5 \mathrm{~h}$ 変化させたときのX線回 折図形の相の解析を行ったものである。なお，仮焼成条件 は $1275^{\circ} \mathrm{C} \times 1.0 \mathrm{~h}$ 一定である。Cu置換量X=0.3については比 較的低い焼成温度 $\left(1175^{\circ} \mathrm{C}\right)$ においてもW相単相となり，こ の置換量が本系BaZnCU-W磁石にとって安定しやすい状態 にあることが知られる。

表1 種々の焼成温度による $\mathrm{BaZn}_{2-\mathrm{x}} \mathrm{Cu}_{\mathrm{x}} \mathrm{Fe}_{16} \mathrm{O}_{27}$ 化合物の相の解析

Table 1 Phases of $\mathrm{BaZn}_{2-\mathrm{x}} \mathrm{Cu}_{\mathrm{X}} \mathrm{Fe}_{16} \mathrm{O}_{27}$ compounds at various sintering temperatures.

\begin{tabular}{|c|c|c|c|c|c|c|}
\hline \multirow{3}{*}{$\begin{array}{c}\text { Ou } \\
\text { content } \\
(X)\end{array}$} & \multicolumn{3}{|c|}{$\begin{array}{l}W: \text { W-phase } \\
\mathrm{S}: \text { Spinel-phase }\left(\mathrm{F}_{\mathrm{F}} \mathrm{O}_{4}\right)\end{array}$} & \multicolumn{3}{|c|}{$\alpha: \alpha-F=0$-phase } \\
\hline & \multicolumn{6}{|c|}{ Sintering temperalure $\left({ }^{\circ} \mathrm{C}\right)$} \\
\hline & 1150 & 1175 & 1200 & 1225 & 1250 & 1275 \\
\hline 0 & $w, a$ & $w, \alpha$ & $w, a$ & $w, \alpha$ & $w, \alpha$ & $w$ \\
\hline 0.1 & $w, \alpha$ & $w, \alpha$ & $w, \alpha$ & $w, a$ & $w$ & $w$ \\
\hline 0.2 & $w, \alpha$ & $w, \alpha$ & $w, \alpha$ & w & $w$ & $w$ \\
\hline 0.3 & $w, a$ & $w$ & $w$ & w & w & $w$ \\
\hline 0.4 & $w, \alpha$ & $w, a$ & $w, \alpha$ & $w, \alpha$ & $w$ & $w$ \\
\hline 0.5 & $W, \alpha, s$ & $w, \alpha, S$ & $w, \alpha$ & $w, \alpha$ & $w, \alpha$ & $w$ \\
\hline 1.0 & $w, \alpha, s$ & $w, a, s$ & $w, \alpha, s$ & $w, a$ & $w, a$ & $w$ \\
\hline
\end{tabular}

Fig.3 は $\mathrm{Cu}$ の置換量を $\mathrm{X}=0.3$ とした組成式 $\mathrm{BaZn}_{1.7} \mathrm{Cu}_{0.3} \mathrm{Fe}_{16} \mathrm{O}_{27}$ の仮焼成温度を $1225^{\circ} \mathrm{C} \sim 1300^{\circ} \mathrm{C} \times$ $1 \mathrm{~h}$ とし, 本焼成温度を $1175^{\circ} \mathrm{C} \sim 1275^{\circ} \mathrm{C} \times 0.5 \mathrm{~h}$ 变化させ たときの磁気特性に及ぼす影響を示している。図から知ら

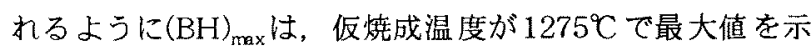
し，この結果より仮焼成条件は $1275^{\circ} \mathrm{C} \times 1.0 \mathrm{~h}$ が適当である と思われる。

以上, $\mathrm{Ba}-\mathrm{Zn}_{2}-\mathrm{W}$ 化合物の $\mathrm{Zn} の 一$ 部を $\mathrm{Cu}$ で置換した磁気 特性について述べてきたが，それほど優れた特性が得られ なかった。そこで, $\mathrm{BaO} \cdot 2 \mathrm{ZnO} \cdot 8 \mathrm{Fe}_{2} \mathrm{O}_{3} に \mathrm{BaO}$ 途中添 加することが磁気特性向上に有效である ${ }^{19}$ ということを見 つけているので, 置換量 $\mathrm{X}=0.30$ 組成に, $\mathrm{BaO}$ 途中添加 することを試みた。

Fig.4情 $\mathrm{BaZn}_{1.7} \mathrm{Cu}_{03} \mathrm{Fe}_{16} \mathrm{O}_{22}$ 化合物において仮焼成条件 $1275^{\circ} \mathrm{C} \times 1.0 \mathrm{~h}$ 一定にし, 本焼成温度を $1150^{\circ} \mathrm{C}, 1175^{\circ} \mathrm{C}$, $1200^{\circ} \mathrm{C}$ で本焼成時間を $0.5 \mathrm{~h}$ 一定としたときの $\mathrm{BaO}$ 添加量(0 〜 $5 \mathrm{w} t \%)$ と磁気特性の関係を示す。図から知られるように 全ての本焼成温度において $\mathrm{J}_{\mathrm{m}} \mathrm{J}_{\mathrm{r}}$ は $\mathrm{BaO}$ 添加量の増加に伴い 增加することが顕著に見られた。また， $\mathrm{H}_{\mathrm{d}}, \mathrm{H}_{\mathrm{CB}}$ はBaOを途 
中添加したことによる傾向はそれほど見られず，ほぼ一定

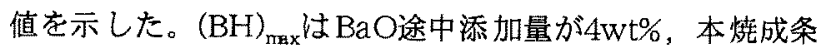
件が $1175^{\circ} \mathrm{C} \times 0.5 \mathrm{~h}$ て最高值を示し，無添加のものに比べ約 $66 \%$ の增加となった。

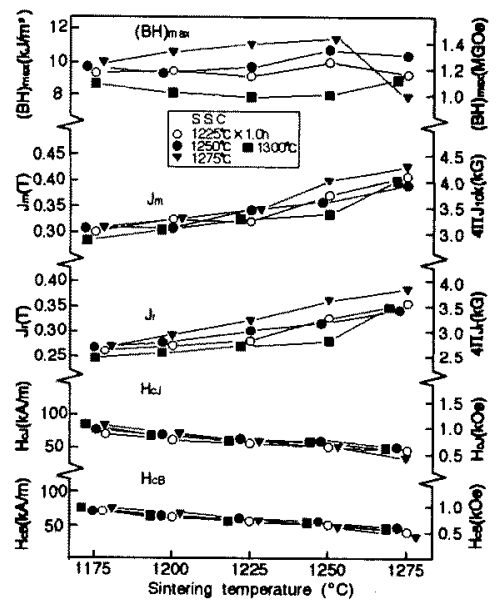

図3 種々の仮焼成による $\mathrm{BaZn}_{1.7} \mathrm{Cu}_{0.3} \mathrm{Fe}_{16} \mathrm{O}_{27}$ 化 合物の磁気特性

Fig.3 Magnetic properties of $\mathrm{BaZn} \mathrm{n}_{1.7} \mathrm{Cu}_{0.3} \mathrm{Fe}_{16} \mathrm{O}_{27}$ compounds at various semisintering temperatures.

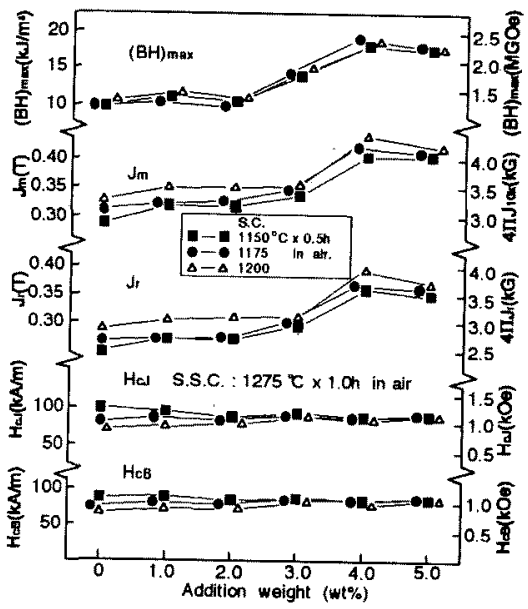

図4 種々の本焼成温度における $\mathrm{BaZn}_{1.7} \mathrm{Cu}_{03} \mathrm{Fe}_{16}$ $\mathrm{O}_{27}$ 化合物の磁気特性に及ぼすBaO添加量影響

Fig.4 Effect of $\mathrm{BaO}$ ad dition after semisinter $\mathrm{i}$ $\mathrm{ng}$ treatmenton magnetic properties of $\mathrm{BaZn}_{1.7}$ $\mathrm{Cu}_{0.3} \mathrm{Fe}_{16} \mathrm{O}_{27}$ compounds at various sintering temperatures.

Fig.5は $\mathrm{BaZn}_{1.7} \mathrm{Cu}_{0.3} \mathrm{Fe}_{16} \mathrm{O}_{27}$ 化合物において仮焼成条件が $1275^{\circ} \mathrm{C} \times 1.0 \mathrm{~h}$ ，本焼成条件が $1175^{\circ} \mathrm{C} \times 0.5 \mathrm{~h}$ としたときの $\mathrm{BaO}$ 添加量別( $0 \sim 5 \mathrm{wt} \%)$ の X線回折図形である。図から知 られるようにBaOの添加量が1wt\%のときはM相の回折線が 見られW相との混相となったが、以降W相単相を得ること
ができた。

Table2はBaZn ${ }_{1.7} \mathrm{Cu}_{03} \mathrm{Fe}_{16} \mathrm{O}_{27}$ 化合物にBaOを0 5wt\% 添 加したときのX線回折図形より相の解析をまとめたもので ある。なお，仮焼成条件は $1275^{\circ} \mathrm{C} \times 1.0 \mathrm{~h}$ と，本焼成温度 はそれぞれの添加量において $1150 \sim 1275{ }^{\circ} \mathrm{C}$ と変化させた。 表から知られるようにBaOを $2 \mathrm{w} \%$ 以上添加した試料では， 本焼成温度が $1175^{\circ} \mathrm{C}$ 以降全てW相単相を得ることができた。

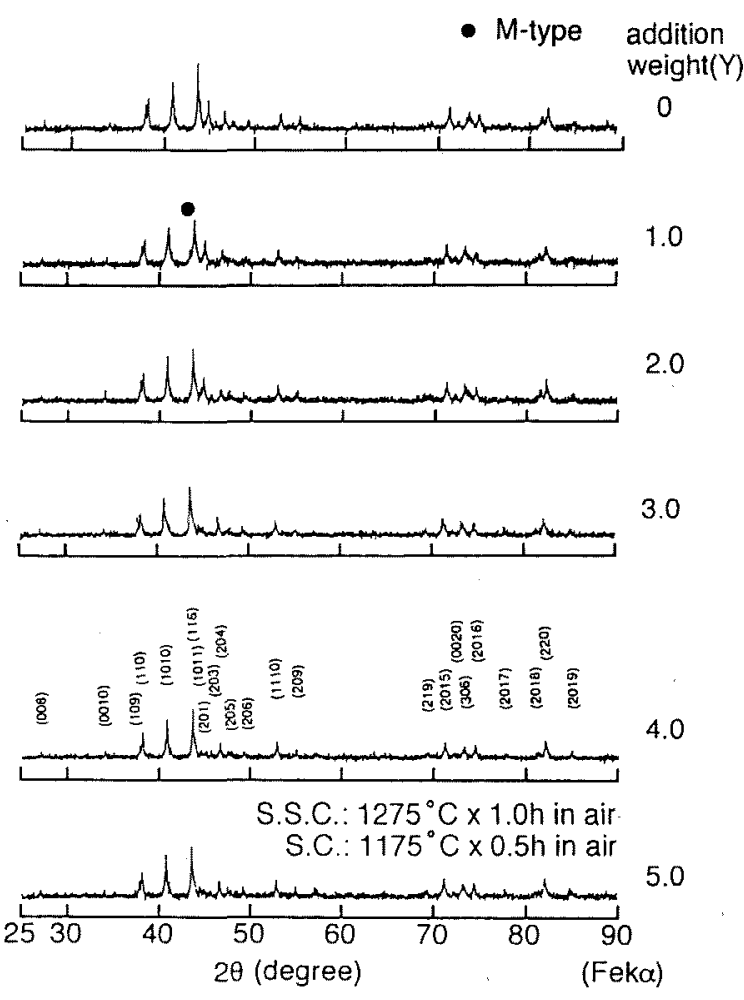

図5 $\mathrm{BaZn}_{1.7} \mathrm{Cu}_{0.3} \mathrm{Fe}_{16} \mathrm{O}_{27}$ 化合物へのBaO添加量に よるX線回折図形

Fig.5 X-ray diffraction patterns of $\mathrm{BaZn}_{1.7}$ $\mathrm{Cu}_{03} \mathrm{Fe}_{16} \mathrm{O}_{27} \mathrm{compounds}$ in addition with Ywt\% BaO after semisintering treatment.

以上の結果より本実験における最適作彆条件は，組成は $\mathrm{BaZn}_{1.7} \mathrm{Cu}_{0.3} \mathrm{Fe}_{16} \mathrm{O}_{27}$ で, 仮焼成条件 $1275^{\circ} \mathrm{C} \times 1.0 \mathrm{~h}, \mathrm{BaO} 4 \mathrm{w}$ t\%途中添加，本焼成条件 $1175^{\circ} \mathrm{C} \times 0.5 \mathrm{~h}$ としたときであっ た。

Fig.6は，本実験で最高の磁気特性を示した試料の $\sigma_{\mathrm{s}}$, 拉よび $\mathrm{H}_{\mathrm{c}}$ の温度依存性を示している。なお。測定は反磁界 を正確に補正するために，化合物を球状 $(\phi=3.0 \mathrm{~mm})$ に加工 し，VSMにより印加磁界を $1600 \mathrm{kA} / \mathrm{m}$ で， $-196 \sim 360^{\circ} \mathrm{C}$ の温度範囲で行った。図から知られる通り，。步は温度の上 昇と共に減少し， $\mathrm{H}_{\mathrm{c}}$ は温度上昇と共に增加し， $210^{\circ} \mathrm{C}$ で最 高值 $144.6 \mathrm{kA} / \mathrm{m}$ をり，その後急激に減少した。これは従 来のM型フェライト同様の傾向となっており， $\mathrm{H}_{\mathrm{g}}$ の增加は 異方性磁界が増えるためと思われる。また図におい て $\sigma_{\mathrm{s}}$ を $-273^{\circ} \mathrm{C}$ まで外挿し, $145.82 \times 10^{-6} \mathrm{wb} \cdot \mathrm{m}$ $/ \mathrm{kg}$ 值を得た。そこで分析値 $\left(\mathrm{Ba}^{2+}{ }_{1.179} \mathrm{Zn}^{2+}{ }_{1464} \mathrm{Cu}^{2+}{ }_{0256}\right.$ 
$\left.\mathrm{Fe}^{2+}{ }_{0238} \mathrm{Fe}^{3+}{ }_{15829} \mathrm{O}_{27}\right)$ より計算したこの化合物の分子量 1603. 2 を用いて一分子当たりの磁気モーメント $n_{\mathrm{B}}$ を計算する と， $\eta_{\mathrm{B}}=33.3 \mu_{\mathrm{B}}$ となった。この值は先に我々が報告 ${ }^{19}$ した $\mathrm{BaO} \cdot 2 \mathrm{ZnO} \cdot 8 \mathrm{Fe}_{2} \mathrm{O}_{3}$ の磁気モーメント $n_{\mathrm{B}}=33.7 \mu_{\mathrm{B}}$ と 比べ若干低い值となっている。

表2 $\mathrm{BaZn}_{1.7} \mathrm{Cu}_{0.3} \mathrm{Fe}_{16} \mathrm{O}_{27}$ 化合物へのBaO添加量に よる相の解析

Table 2 Phases of $\mathrm{BaZn}_{1.7} \mathrm{Cu}_{03} \mathrm{Fe}_{16} \mathrm{O}_{27} \mathrm{com}^{-}$ pounds in addition with $\mathrm{BaO}$ after semisintering treatment.

\begin{tabular}{|c|c|c|c|c|c|c|}
\hline \multirow{3}{*}{ 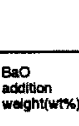 } & $\begin{array}{l}W: M \\
M: M\end{array}$ & $\begin{array}{l}\text { phase } \\
\text { phase }\end{array}$ & \multicolumn{4}{|c|}{$\alpha: \alpha-F_{e r O}-$ phase } \\
\hline & \multicolumn{6}{|c|}{ Sintering temperature $\left({ }^{\circ} \mathrm{C}\right)$} \\
\hline & 1150 & 1175 & 1200 & 1225 & 1250 & 1275 \\
\hline 0 & $w, \alpha$ & w & $w$ & $w$ & $w$ & $w$ \\
\hline 1.0 & W.M & W.M & $w$ & w & w & $w$ \\
\hline 2.0 & $w, M$ & w & $w$ & w & w & $w$ \\
\hline 3.0 & $w, M$ & $w$ & $w$ & w & $w$ & $w$ \\
\hline 4.0 & $w, M$ & $w$ & $w$ & w & w & $w$ \\
\hline 5.0 & $w_{i} M$ & $w$ & w & $w$ & $w$ & $w$ \\
\hline
\end{tabular}
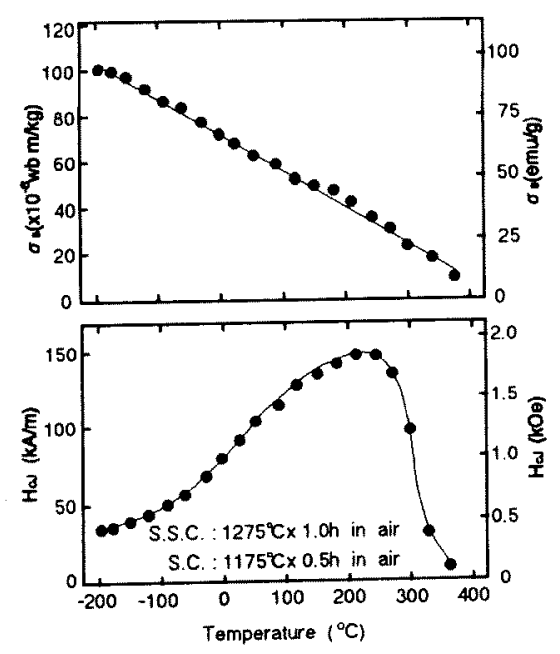

図6 $\quad \mathrm{BaZn}_{1.7} \mathrm{Cu}_{03} \mathrm{Fe}_{16} \mathrm{O}_{27}$ 化合物に $4 \mathrm{wt} \% \mathrm{BaO}$ を 添加した試料の温度依存性

Fig.6 Temperarure dependence on magnetic properties of $\mathrm{BaZn}_{1.7} \mathrm{Cu}_{0.3} \mathrm{Fe}_{16} \mathrm{O}_{27}$ compound in addition with $4 \mathrm{wt} \% \mathrm{BaO}$ after semisintering treatment.

Fig.7はBaZn ${ }_{17} \mathrm{Cu}_{0.3} \mathrm{Fe}_{16} \mathrm{O}_{27}$ 化合物に対するBaO添加量の キュリー温度に及ぼす影響を示している。測定はVSMを用 いて的加磁界零で測定したものである。キュリ一温度厂。は
$\mathrm{BaO}$ を添加することにより減少していくことが知られた。 この原因については，BaOが固溶すること，及びBaOを添 加することによりC軸の格子定数が減少していくことに原 因があると考えられるが，詳細についてはよくかからない。 なお最高の磁気特性が得られた BaOを $4 \mathrm{w} t$ t\%添加したとき の試料のキュリー温度 $\mathrm{T}_{c}$ は $356.0^{\circ} \mathrm{C}$ であった。

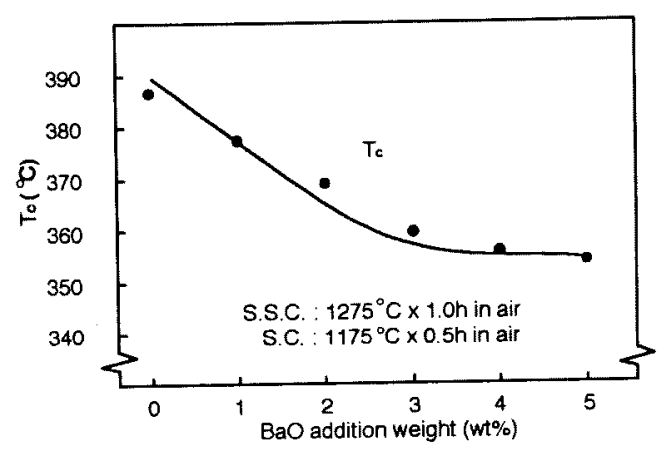

図7 $\mathrm{BaZn}_{1.7} \mathrm{Cu}_{03} \mathrm{Fe}_{16} \mathrm{O}_{27}$ 化合物へのBaO添加量 によるキュリ一温度

Fig.7 Curie te mperature of $\mathrm{BaZn}{ }_{1.7} \mathrm{Cu}_{03} \mathrm{Fe}_{16}$ $\mathrm{O}_{27}$ compounds in addition with $\mathrm{BaO}$ after semisintering treatment.

Fig.8は本実験で最良の磁気特性を示した $\mathrm{BaZn}_{1.7} \mathrm{Cu}_{0.3} \mathrm{Fe}_{16} \mathrm{O}_{27}$ 化合物に仮焼成後 $\mathrm{BaO} 4 \mathrm{wt} \%$ 添加した ものと、無添加のBa-Zn系の基本組成において、同じ焼成 条件で作製した試料の組織写真を示す。写真から知られる ように、試料作製時のプレス時の印加磁界に垂直方向（@） からは六角板状組織が、平行方向（个）からは偏平板状組 織が観察され、これは従来の六方晶系M型フェライト同様 となっている。なお、若干であるが本実験最良の試料の粒 径のほうが $\mathrm{Ba}-\mathrm{Zn}$ 系の基本組成の粒径に比べて小さくなつ ており、また、平均粒径は約 $2 \mu \mathrm{m}$ 程度である。

Fig.9は本実験において最高の磁気特性を示した $\mathrm{BaZn}_{1.7} \mathrm{Cu}_{0.3} \mathrm{Fe}_{16} \mathrm{O}_{27}$ 化合物にBaO添加量 $4 \mathrm{wt} \%$ とした試料の 磁区模様をビッター法を用いて観察したものである。 試料は，観察を容易にするために本焼成温度 $1325^{\circ} \mathrm{C} \times 2.0 \mathrm{~h}$ とし粒成長させたものを用いた。写真から知られるように 試料の作製時の印加磁界に対して垂直方向（@）は迷 路磁区が，平行方向（や）からは180度磁区が観察され， これも従来の六方晶系M型フェライト同様となっている。

Table 3 は，本実娩で最高の磁気特性が得られた $\mathrm{BaZn}_{1.7} \mathrm{Cu}_{0.3} \mathrm{~F} \mathrm{~F}_{16} \mathrm{O}_{27}$ 化合物にBaOを $4 \mathrm{wt} \%$ 途中添加した焼結 磁石の磁気的，物理的特性を示した。なお， $\mathrm{K}_{\mathrm{A}}, \mathrm{H}_{\mathrm{A}}$ は焼 結磁石を10個作製し, 一片7 mmの立方体に切り出し, 容 易方向之困難方向の磁化曲線を描き，外挿法により $\mathrm{H}_{\mathrm{A}}$ を求 め $\mathrm{K}_{\mathrm{A}}=\mathrm{J}_{\mathrm{m}} \cdot \mathrm{H}_{\mathrm{A}} / 2$ の式で算出した。その結果, 異方性定数 $\mathrm{K}_{\mathrm{A}}$ は, $2.01 \times 10^{5} \mathrm{~J} / \mathrm{m}^{3}$, 異方性磁界 $\mathrm{H}_{\mathrm{A}}$ は, $994.7 \mathrm{kA} / \mathrm{m}$ あっ た。また密度は $4.82 \mathrm{Mg} / \mathrm{m}^{3}$ であった。 


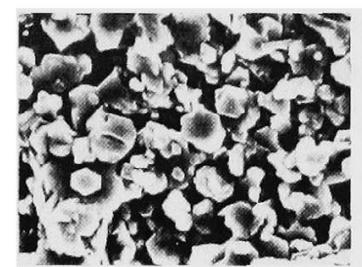

$\overline{1 \mu \mathrm{m}}$

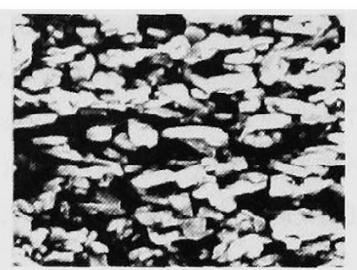

$1 \overline{\mu m}$
No addition

H $\odot$ S.S.C. : $1275^{\circ} \mathrm{C} \times 1.0 \mathrm{~h}$ in air $\mathrm{H} \uparrow$ S.C. : $1175^{\circ} \mathrm{C} \times 0.5 \mathrm{~h}$ in air

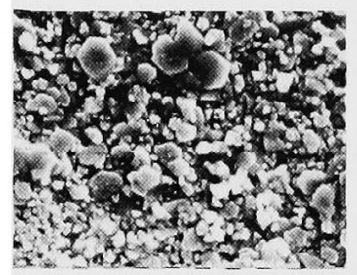

$\overline{1 \mu m}$

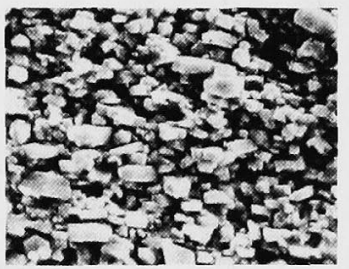

$1 \mu \mathrm{m}$
$4 \mathrm{wt} \% \mathrm{BaO}$ addition

図8 $\mathrm{BaZn}_{1.7} \mathrm{Cu}_{03} \mathrm{Fe}_{16} \mathrm{O}_{27}$ 化合物に $4 \mathrm{wt} \% \mathrm{BaO}$ 添加した試料の組織写真

Fig.8 SEM photographs of $\mathrm{BaZn}_{1.7} \mathrm{Cu}_{0.3} \mathrm{Fe}_{16} \mathrm{O}_{27}$ compounds in addition with $4 \mathrm{wt} \% \mathrm{BaO}$ after semisintering treatment.

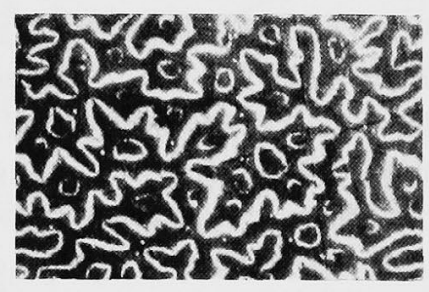

$1 \overline{\mu m}$

$\mathrm{H}$ ○

(A) Surface perpendicular to the easy direction

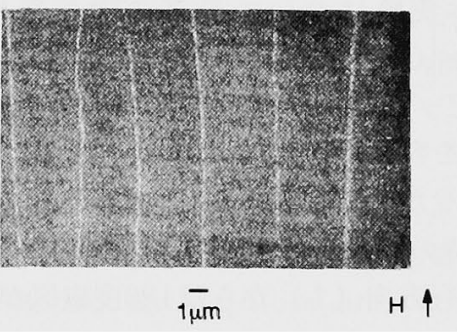

(B) Surface parallel to the easy direction S.S.C.: $1275^{\circ} \mathrm{C} \times 1.0 \mathrm{~h}$ in air S.C.: $1325^{\circ} \mathrm{C} \times 2.0 \mathrm{~h}$ in air

図9 $\mathrm{BaZn}_{1.7} \mathrm{Cu}_{03} \mathrm{Fe}_{16} \mathrm{O}_{27}$ 化合物に $4 \mathrm{wt} \% \mathrm{BaO}$ 添加した試料の磁区模様

Fig.9 Magnetic domain structures of $\mathrm{BaZn}{ }_{1.7} \mathrm{Cu}_{03} \mathrm{Fe}_{16} \mathrm{O}_{27}$ magnet in addition with $4 \mathrm{wt} \% \mathrm{BaOafter}$ semisintering treatment.
表3 $\mathrm{BaO}$ 添加量を $4 \mathrm{w} \%$ とした $\mathrm{BaZn}_{17} \mathrm{Cu}_{03} \mathrm{Fe}_{16}$ $\mathrm{O}_{27}$ 化合物の磁気的及び物理的特性

Table 3 Magnetic and physical properties of $\mathrm{BaZn} \mathrm{n}_{1.7} \mathrm{Cu}_{0.3} \mathrm{Fe}_{16} \mathrm{O}_{27}$ compound in addition with $4 \mathrm{wt} \% \mathrm{BaO}$ after semisintering treatment.

\begin{tabular}{|c|c|c|}
\hline \multicolumn{3}{|c|}{ 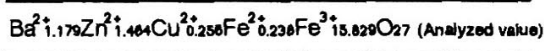 } \\
\hline \multirow{9}{*}{$\begin{array}{l}\text { Magnetic } \\
\text { properties }\end{array}$} & $\operatorname{Jm}(T)$ & 0.405 \\
\hline & $\operatorname{Jr}(\mathrm{T})$ & 0.370 \\
\hline & $H_{\omega}(k A / m)$ & 88.15 \\
\hline & $\mathrm{HCB}_{\mathrm{C}}(\mathrm{kA} / \mathrm{m})$ & 81.96 \\
\hline & $(\mathrm{BH})_{\max }\left(\mathrm{kJ} / \mathrm{m}^{3}\right)$ & 19.12 \\
\hline & $K_{A}\left(x 10^{5} \mathrm{~J} / \mathrm{m}^{3}\right)$ & 2.01 \\
\hline & $H_{A}(\mathrm{kA} / \mathrm{m})$ & 994.7 \\
\hline & $\sigma s\left(x 10^{-6} \mathrm{~Wb} \cdot \mathrm{m} / \mathrm{kg}\right)$ & 87.09 \\
\hline & $\eta_{\theta}\left(\mu_{\theta}\right)$ & 33.3 \\
\hline Density & $\left(\mathrm{Mg} / \mathrm{m}^{3}\right)$ & 4.82 \\
\hline $\begin{array}{l}\text { Curie } \\
\text { temperature }\end{array}$ & $\left({ }^{\circ} \mathrm{C}\right)$ & 356 \\
\hline $\begin{array}{l}\text { Lattice } \\
\text { constant }\end{array}$ & $\begin{array}{c}a\left(\times 10^{-10} \mathrm{~m}\right) \\
c\left(\times 10^{-10} \mathrm{~m}\right) \\
c / a\end{array}$ & $\begin{array}{l}5.927 \\
32.928 \\
5.556\end{array}$ \\
\hline Molecular waight & M.W. & 1603.2 \\
\hline
\end{tabular}

\section{4 結言}

異方性 $\mathrm{Ba}-\mathrm{Zn}-\mathrm{Cu}$ 系W型フェライト磁石についてまとめ ると次の通りである。

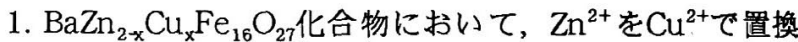
することにより仮焼成時W相単相が得られ，本焼成後も比 較的高い焼成温度で安定にW相単相が得られた。磁気特性 についてはCu置換量 $\mathrm{X}=0.3$ こき $(\mathrm{BH})_{\max }$ が最大となったが, 無置換と比較して大きな向上は見られなかった。

2. $\mathrm{BaZn}_{1.7} \mathrm{Cu}_{03} \mathrm{Fe}_{16} \mathrm{O}_{27}$ 化合物にBaOを途中添加することに より低い焼成温度でW相単相を得ることができ，(BH $)_{\max }$ も 添加前の値に比べて約66\%の增加となった。

3. 本実験において最高の磁気特性が得られた試料は, 組成 式 $\mathrm{BaZn}_{2-\mathrm{x}} \mathrm{Cu}_{\mathrm{x}} \mathrm{Fe}_{16} \mathrm{O}_{27}$ において, $\mathrm{Cu}$ 置換量 $\mathrm{X}=0.3$ とし, $\mathrm{BaO}$ twt\%途中添加したものである。その時の作製条件 及び磁気特性は次のようである。

仮焼成条件 $1275^{\circ} \mathrm{C} \times 1.0 \mathrm{~h}$ in air $\times 0.5 \mathrm{~h}$ in $\operatorname{air}$ のと $(\mathrm{BH})_{\max }=19.12 \mathrm{~kJ} / \mathrm{m}^{3}$ が得られた。

(平成10年10月 1 日受付, 平成 10 年 12 月 9 日再受付)

\section{文献}

1) J. J. Went, G. W. Rethenau, E. W. Goter and G.W. Van Oosterhout : Philips Tech Rev.,13(1952)194.

2) P. B. Braun : Nature, 170(1952)708. 
3) L.G.Van Uitert, M. H. Read and F. J. Schnettler : J. Appl. Phys., 28(1957)280.

4) L. G. Van Uitert and F. W. SwaneKamp : J. Appl. Phys., 28(1957)482.

5) J. Smit and H. P. J. Wijn, Ferrites : Philips Tech. Libary;(1959)

6) Y. Goto, M. Higashimoto and and K. Takahashi : Appl. Phys., 12(1973)945

7) F. K. Lotgering, P. R. Locher and R. P. Van Stapele :J.Phys. Chem. Solids, 41 (1980)481.

8) H. Graetsch, F. Haberey, R. Leckebusch, M. S. Rosenberg and K. Sahl : IEEE Trans Magn., vol.MAG-20(1984)495.

9) T.Besagni,A.Deriu,F.Licci,L.Pareti andS.Rinald $\mathrm{i}$ "Nickel and Copper Substitution in Zn2-W",IEEE Trans.Magn.,vol.MAG-17,p.2636,1981

10) F.Licci, L.Pareti and S.Rinald i, " $\mathrm{Zn} 2 \mathrm{~W}$ : Improvements of Magnetic Properties by Copper substitution", J.Appl. Phys.,vol.52,p.2526,1981.

11) H.Kojima, C.MIyakawa, T.Sato and K. Goto, "Magnetic Prperties of W-type Hexaferrite powders", Japan.J.Appl.Phys.,vol.24,p.51,1985

12）山元 洋, 永倉 充, 小野秀明, 高橋愛明: 粉体および粉末治金, 34(1987)269.

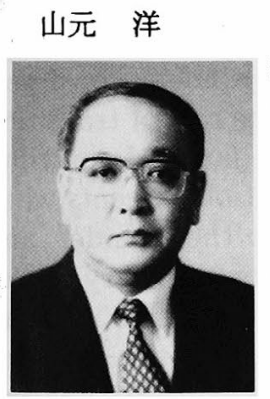

（正員）1941年3月23日生。1969年明 治大学大学院工学研究科電気工学専攻 博士課程修了。以後, 同大学工学部 (現在, 理工学部) 電気工学科助手, 講師, 助教授を経て, 現在, 同教授。 工学博士。この間, 1984年3月〜 月 アイオワ州立大学電工学科客員教授。 主として, 磁性材料に関する研究に従 事。1995年粉末粉体冶金協会研究功 續賞受賞。IEEE, 日本応用磁気学 会, 日本金属学会, 粉末粉体冶金協会 会員。
13) H. Yamamoto, M. Nagakura and H. Ono : IEEE Trans. Magn., 24(1988)598.

14) A.Collomb, G.Litsarkakis, J. P. Mignot and D.Samaras : IEEE Trans. Magn.,24(1988)1936.

15) S. Ram and J. C. Joubert : Phys. Rev., 44(1991)6825.

16) H. Yamamoto, D. Yamada and T. Nakajima : IEEE Trans. Magn., 28(1992)2868.

17) S. Ram and J. C. Joubert : IEEE Trans. Magn., 28(1992) 15.

18) H. Yamamoto, T. Maki and T. Takahashi : Proc. of 6th ICF, Tokyo, the Japan. Soc. Powder and P owder Metallurgy, (1992)1133.

19) 山元 洋, 石井章雄: 日本応用磁気学会誌, 17(1993) 175 .

20) H. Yamamoto, H. Fujii and T. Mi tsuoka : Proc. of the Third Internatinal Symposium on Physics of MagneticMaterials, Seoul, Korea, (1996)1031.

21）豊田幸夫：粉体および粉末冶金，44(1997)17.

22）久保田, 緒方: 粉体粉末冶金協会, 平成 10 年度 春季大会講演概要集, 2-52A(1998)p.207.

23）山元 洋, 蝶野正浩: 粉体および粉末冶金, 44(1997)612.

24）山元, 蝶野, 鈴木, 明治大学科学技術研究所紀要, 36(5):p.53.1997.

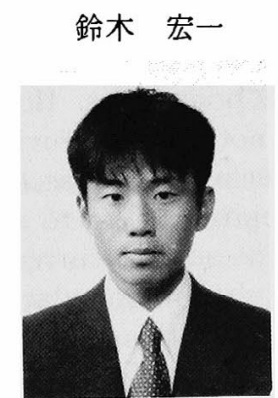

（非会員）1974年9月3日生。1999年3 月明治大学大学院理工学研究科電気 工学専攻修士課程修了。同年, 松下 電器産業株式会社) 入社, 現在に至 る。 